\title{
ORGANIC INDUSTRIAL WASTES AS SUBSTRATES FOR BUTANOL BIOSYNTHESIS BY CLOSTRIDIUM BACTERIA
}

\author{
S. Skrotskyi \\ Danylo Zabolotny Institute of Microbiology and Virology of the NASU
}

\begin{tabular}{l}
$\quad$ Key words: \\
Bacteria of Clostridium \\
genus \\
Butanol \\
Whey \\
Poultry litter \\
\hline
\end{tabular}

Article history:

Received 07.03.2018

Received in revised form

26.03.2018

Accepted 18.04.2018

Corresponding author:

S. Skrotskyi

E-mail:

bio-imv@ukr.net

\begin{abstract}
It has been established that Clostridium strains are active producers of butanol that is formed during the process of fermentation on such industrial wastes as whey (by-product of the dairy industry) and poultry litter (waste of poultry farming). A comparative analysis of the chemical composition of different types of whey (dairy and sour milk) was conducted. The general chemical composition of chicken droppings has been analyzed. An assumption was made that whey and poultry droppings can be used as the main, single or auxiliary components of the substrate for acetone-butyl alcohol fermentation to produce biobutanol. The dynamics of $\mathrm{pH}$ change in the culture of clostridia in rye media was analyzed. It was found that for strains of bacteria SS- 1 and SS-5 there was a change of $\mathrm{pH}$, which does not correspond to classical acetone-butyl fermentation.

It was shown the ability to synthesize butanol with the use of natural nutrient media based on grain crops (barley, rye, corn, wheat, oats). The largest amount of butanol was produced using rye media (SS-2 strain - $11.2 \mathrm{~g} / \mathrm{l}$ ). Clostridium SS-1 and SS-5 isolates produced 12\% less of butanol in this media than other samples, which may be due to deviations in $\mathrm{pH}$ changes during fermentation.

Clostridium strains can ferment whey and poultry litter to fatty acids, butanol, organic solvents and gases. The highest butanol production of $9.2 \mathrm{~g} / \mathrm{l}$ was observed in the complex media composed of chicken litter and whey in 30:70 volume ratio while only $4.8 \mathrm{~g} / \mathrm{l}$ of butanol was produced in chicken litter medium. The obtained results attest to the great potential of such wastes as substrates for cheap biofuel production provided that substrate pre-treatment and fermentation conditions are optimized.
\end{abstract}

DOI: $10.24263 / 2225-2924-2018-24-2-6$

\section{ОРГАНОВМІСНІ ВІДХОДИ ВИРОБНИЦТВА ЯК СУБСТРАТИ ДЛЯ БІОСИНТЕЗУ БУТАНОЛУ БАКТЕРІЯМИ РОДУ CLOSTRIDIUM}

\section{С.О. Скроцький}

Інститут мікробіології і вірусології ім. Д.К. Заболотного НАН України

У статті встановлено, що бактерії роду Clostridium є активними продуцентами бутанолу, який утворюється в процесі бродіння на відходах 
виробництв - активних забруднювачах навколишнього середовища (відходи птахівництва - послід птиці) та відходах молочної промисловості (молочна сироватка). Проведено порівняльний аналіз хімічного складу різних видів сироватки (підсирна та кисломолочна). Проаналізовано загальний хімічний склад курячого посліду. Зроблено припущзення, щзо молочна сироватка та пташиний послід можуть бути використані для отримання біобутанолу як основні, єдині або допоміжні компоненти субстрату для ацетоно-бутилового зброджування. Проаналізовано динаміку зміни рН при культивуванні клостридій на житньому середовищі. Виявлено, щуо для итамів бактерій SS-1 ma SS-5 спостерігалась зміна рН, що не відповідає класичному ацетоно-бутиловому бродінню.

Показано здатність до синтезу бутанолу при використанні природних поживних середовищ на основі зернових культур (ячмінь, жито, кукурудза, пшениця, овес). Найбільша кількість бутанолу продукувалась при використанні житнього середовища (штам SS-2 - 11,2 г/л). Ізоляти клостридій SS-1 та SS-5 продукували на даному середовищі на 12 \% менше бутанолу порівняно з іншими зразками, що може бути пов'язано з відхиленнями зміни рН у процесі бродіння.

Встановлено, щзо виділені раніше итами роду Clostridium здатні зброджувати молочну сироватку та курячий послід з виділенням жирних кислот, бутанолу, інших органічних розчинників і газів. Найбільша кількість бутанолу синтезувалась на комплексному середовищі (курячий послід + молочна сироватка у співвідношенні 30:70\%) та максимально становила 9,2 г/л, а на середовищі з курячим послідом його кількість досягала значень 4,8 г/л. Це свідчить про значний потенціал використання відходів як субстратів для отримання дешевого біопалива при умові ефективної оптимізації як попередньої їх підготовки, так і умов проведення самого процесу зброджування.

Ключові слова: бактерї роду Clostridium, бутанол, молочна сироватка, курячий послід.

Постановка проблеми. Останніми роками велика увага приділяється активному впровадженню в різні сфери промисловості різноманітних біопалив, які мають такі основні переваги: незалежність від світових цін на нафту, низька ціна, обумовлена використанням місцевої сировини для виробництва біопалива, а також його екологічна чистота. Тому цілком логічним є пошук можливості використання як субстратів для отримання біопалив різноманітних відходів народного господарства - масових забруднювачів навколишнього середовища, а також дослідження активних штамів бактерій, які продукують бутанол. При такому підході не тільки будуть вирішуватись питання енергетики, а й значні екологічні проблеми. Такий підхід забезпечить значне підвищення рентабельності виробництва біопалива навіть при його нижчому абсолютному виході, оскільки основою для отримання біопалива будуть не просто дешеві субстрати, а й такі, що підлягають обов'язковій (зазвичай платній) утилізації.

Беручи до уваги такі аспекти відходів, як велика кількість, складність утилізації та хімічний склад, який дає змогу провести процес бутилового 
зброджування, перспективними для досліджень $є$ відходи молочної промисловості (молочна сироватка) та птахівництва (курячий послід).

За даними сайту http://infagro.com.ua/ за 2017 рік в Україні виробництво молока всіма категоріями господарств склало 10,321 млн тонн. Врахувавши, що вихід молочної сироватки з 1 т молока становить від $65 \%$ до $82 \%$, ми отримаємо $6,7 \div 8,46$ млн тонн сироватки. При цьому світове виробництво сироватки складає більше 160 млн тонн на рік [1], і з кожним роком ця цифра збільшується. При цьому слід наголосити, що 1 т молочної сироватки, що зливається в каналізацію, забруднює водойми так само, як $100 \mathrm{~m}^{3}$ господарсько-побутових стоків [2].

Молочна сироватка містить велику кількість тваринного білка і вуглеводів, які, потрапляючи в навколишне середовище, руйнуються і створюють стійке органічне забруднення території. При зливі в грунт нативної або розведеної водою молочної сироватки відбувається пригнічення розвитку рослин, а при тривалому їі надходженні зменшується родючість грунту. Висока кислотність молочної сироватки $(\mathrm{pH} 4,9)$ призводить до закислення грунту, внаслідок чого відбувається інгібування сапрофітної мікрофлори. Потрапляючи у воду або грунт, органічні речовини сироватки піддаються окисленню, в результаті чого утворюється велика кількість отруйних сполук. Слід наголосити, що для повного окислення 1 літра молочної сироватки потрібно до 50 літрів кисню, тому при іiі потраплянні у водойми спостерігається зменшення концентрації розчиненого кисню, що веде до загибелі флори і фауни цієї водойми [3].

Разом із тим молочна сироватка є біологічно цінним продуктом, в якій наявні білки $(0,5 \div 1,4 \%)$, лактоза $(3,2 \div 5,1 \%)$, вітаміни, органічні кислоти, мінеральні солі та мікроелементи [4]. Оскільки клостридії здатні рости на поживному середовищі з лактозою як єдине джерело вуглецю завдяки здатності продукувати фермент $\beta$-галактозидазу [5], що необхідна для гідролізу лактози, теоретично можливим $€$ виробництво бутанолу із молочної сироватки.

Щодо другого відходу промисловості - пташиного посліду як перспективного субстрату для отримання бутанолу, то, за даними Державної дослідної станції птахівництва Національної академії аграрних наук України, річний вихід посліду в птахівницьких господарствах України складає близько 4,7 млн тонн. За нинішніх темпів розвитку птахівництво може стати основним джерелом забруднення довкілля відходами виробництва тваринного походження. Послід $є$ джерелом забруднення повітря, грунтів, водоймищ і підземних вод токсичними речовинами, хвороботворними мікроорганізмами (бактерії родів Escherichia, Chlostridium, Salmonella), яйцями та личинками мух і гельмінтів. При розкладанні органічних речовин з курячого посліду виділяється аміак, метан, сірководень, окис вуглецю та інші шкідливі сполуки. Під його складування та зберігання з господарського обороту вилучаються великі площі сільгоспугідь, а стічні води промислових птахівничих комплексів за багатьма параметрами перевищують встановлені нормативи щодо їх скиду у водойми [6-9].

Якщо врахувати, що щоденно від однієї птахофабрики середньої потужності 400 тис. курей-несучок або 9 млн курчат-бройлерів поступає більше 100 т посліду, то зрозумілою стає проблема його утилізації. При цьому від посліду намагаються позбутися простими і малозатратними способами - зливання 
послідної маси в яри, зберігання на несанкціонованих ділянках, на полях, у лісі, поблизу доріг місцевого призначення, в спеціальних бетонованих заглибленнях, які весною і восени завжди заповнені атмосферними опадами i поверхневими водами. Таким чином, стає зрозумілим факт, що видалення 3 птахофабрик великих обсягів посліду $є$ найбільш значущим екологічним чинником дії на навколишнє середовище [10].

Мета статті: аналіз потенційної можливості використання як основи субстратів для отримання біобутанолу органовмісних відходів (молочна сироватка, курячий послід), що $є$ масовими забруднювачами навколишнього середовища, а також експериментальна перевірка фактичної можливості використання цих відходів, без будь-якої попередньої їх підготовки, як джерела для отримання біобутанолу.

Матеріали і методи. Для розуміння можливості зброджування бактеріями роду Clostridium вибраних субстратів у нативному стані не проводили будьякої їх підготовки, направленої на додатковий лізис їх складових (гідроліз, ферментоліз тощо). Всі підготовчі роботи обмежувались тільки забезпеченням стерильності процесу зброджування як умови отримання адекватних даних.

Визначення хімічного складу сироваток. У дослідах використовували підсирну та кисломолочну сироватку, отриману після приготування домашнього сиру та кислого молока. У сироватці визначали масову частку білка рефрактометричним методом (ГОСТ 25179-90 «Молоко. Методы определения белка»), масову частку жиру кислотним методом (ГОСТ 5867-90 «Молоко и молочные продукты. Методы определения жира»), лактозу — фотометричним методом (ГОСТ Р 51259-99 «Молоко и молочные продукты. Метод определения лактозы и галактозы»), кислотність - методом титрування (ГОСТ 362492 «Молоко и молочные продукты. Титриметрические методы определения кислотности»).

Визначення хімічного складу курячого посліду. Зразки курячого посліду брали 3 домашніх господарств. Визначення загального азоту проводили методом К'єльдаля за ГОСТ 26715-85 «Удобрения органические. Методы определения общего азота». Визначення амінного азоту проводили за методом Серенсена (метод формольного титрування). Принцип методу грунтується на блокуванні формальдегідом вільних аміногруп і титруванні лугом еквівалентної кількості карбоксильних груп. Визначення вуглецю проводили за ГОСТ 27980-88 «Удобрения органические. Методы определения органического вещества». Визначення клітковини проводили за ГОСТ 13496.2-91 «Корма, комбикорма, комбикормовое сырье. Метод определения сырой клетчатки». Визначення загального фосфору у перерахунку на $\mathrm{P}_{2} \mathrm{O} 5$ проводили за ГОСТ 26717-85 «Удобрения органические. Метод определения общего фосфора». Визначення загального калію у перерахунку на $\mathrm{K}_{2} \mathrm{O}$ проводили за ГОСТ 26718-85 «Удобрения органические. Метод определения общего калия».

Підготовка курячого посліду. 3 єдиної партії посліду брали певну наважку, заливали киплячою дистильованою водою (з розрахунку 200 г/л). Упродовж 1,5 год проводили екстракцію при $60^{\circ} \mathrm{C}$, безперервно помішуючи [11]. Для приготування середовища використовували всю утворену суспензію. Отриманий об'єм суспензії розливали у флакони або колби по 50-100 мл та 
стерилізували при 1,5 атм 30 хвилин. Після стерилізації вимірювали інтенсивність кольору та $\mathrm{pH}$.

Продуценти бутанолу. У дослідженні використовували ацетоно-бутилові бактерії (АББ) роду Clostridium, що були виділені раніше [12]:

$\begin{array}{ll}\text { Номер штаму: } & \text { Джерело виділення: } \\ \text { SS-1 } & \text { Активний мул водочисних споруд } \\ \text { SS-2 } & \text { Курячий послід } \\ \text { SS-3 } & \text { Гній коров'ячий } \\ \text { SS-4 } & \text { Грунт 3 міського звалища } \\ \text { SS-5 } & \text { Силосна яма }\end{array}$

Поживні середовища. Для дослідження динаміки зміни $\mathrm{pH}$ у процесі бродіння використовували синтетичне середовище такого складу (г/л): глюкоза $2 \mathrm{O} ; \mathrm{KH}_{2} \mathrm{PO}_{4}-0,5 ; \mathrm{K}_{2} \mathrm{HPO}_{4} 3 \mathrm{H}_{2} \mathrm{O}-0,5 ; \mathrm{MgSO}_{4} \times 7 \mathrm{H}_{2} \mathrm{O}-0,2 ; \mathrm{MnSO}_{4} \times 5 \mathrm{H}_{2} \mathrm{O}-$ 0,$01 ; \mathrm{FeSO}_{4} \times 7 \mathrm{H}_{2} \mathrm{O}-0,01, \mathrm{NaCl}-0,01$; ацетат амонію $-2,2$; параамінобензойна кислота $-0,001$; біотин $-0,00001$. Для дослідження інтенсивності утворення розчинників ацетоно-бутиловими бактеріями використовували $6 \%$ затори таких натуральних середовищ: ячмінний, житній, вівсяний, кукурудзяний, пшеничний, а також середовище Рушмана (г/л): картопля - 200,0; глюкоза - 5,0; сульфат амонію - 1,0; карбонат кальцію - 3,0; водопровідна вода. Для приготування вказаних середовищ використовували борошно відповідних зернових культур, яке розводили водою до 6\% концентрації. Для попереднього гідролізу крохмалю розведене у воді борошно витримували при температурі $37^{\circ} \mathrm{C}$ упродовж 2 год, після чого стерилізували в автоклаві упродовж 2 год при температурі $126^{\circ} \mathrm{C}$ і тиску 1,5 атмосфери.

Визначення бутанолу. В процесі ацетоно-бутилового бродіння, крім бутанолу, виділяється етанол, тому для визначення його концентрації використовували метод кількісного визначення бутанолу та етанолу за їх одночасної наявності у розчині. Метод розроблений Б.М. Нахмановичем на основі окислення спиртів і ацетону біхроматом калію за наявності сірчаної кислоти при двох різних за ступенем жорсткості умовах. Витрати біхромату калію на окислення спирту й ацетону зростають 3 підвищенням концентрації сірчаної кислоти, в той час як етиловий спирт кількісно окислюється в оцтову кислоту в достатньо широких межах концентрації сірчаної кислоти й тривалості нагрівання при $100^{\circ} \mathrm{C}$. Під час проведення визначення вмісту розчинників створювали м'які та жорсткі умови та користувались встановленими граничними витратами біхромату калію при окисленні ацетону, бутилового та етилового спиртів; ці величини становили, відповідно, $\alpha_{\mathrm{m}}=0,36 ; \alpha_{\text {ж }}=8,05$; $\beta_{\mathrm{M}}=3,52 ; \beta_{\text {ж }}=11,26 ; \gamma_{\mathrm{M}}=\gamma_{\text {ж }}=4,25$ (в грамах $\mathrm{K}_{2} \mathrm{Cr}_{2} \mathrm{O}_{7}$ на 1 г речовини) [13].

Результати досліджень обробляли статистичними методами [14]. Підрахунки проводили за допомогою IBM РС з використанням пакета програмних засобів Microsoft Excel [15].

Результати і обговорення. Різні види молочної сироватки відрізняються за вмістом лактози, пептидів, білків, амінокислот, вітамінів, тому потрібно провести порівняльний аналіз різних іiі видів для визначення потенційно найоптимальнішого субстрату для бутилового зброджування. Також відомо, що різні види сироватки мають деякі відмінності і за мікроелементним $\mathrm{i}$ 
вітамінним складом, але вони є несуттєвими для первинного визначення потенційної можливості використання сироватки для бутилового й ацетобутилового зброджування. Саме тому було визначено хімічний склад підсирної та кисломолочної сироваток (табл. 1).

Таблиця 1. Хімічний склад різних видів сироватки

\begin{tabular}{|c|c|c|c|}
\hline № & Складова частина (компонент) & Підсирна сироватка & $\begin{array}{c}\text { Кисломолочна } \\
\text { сироватка }\end{array}$ \\
\hline 1 & Вода, \% & $95,0 \pm 2,5$ & $94,0 \pm 2,5$ \\
\hline 2 & Білки, \% & $1,01 \pm 0,05$ & $1,21 \pm 0,05$ \\
\hline 3 & Жири, \% & $0,041 \pm 0,02$ & $0,05 \pm 0,02$ \\
\hline 4 & Лактоза, \% & $4,6 \pm 0,2$ & $3,8 \pm 0,2$ \\
\hline 5 & Кислотність, $^{\circ} \mathrm{T}$ & $57,4 \pm 2,1$ & $61,5 \pm 2,3$ \\
\hline
\end{tabular}

Далі було проаналізовано загальний хімічний склад курячого посліду. При цьому працювали 3 послідом вологістю 75\%, але оскільки на різних птахівничих фермах впроваджені різні технології обробки курячого посліду, то в табл. 2 наведені середні результати дослідження в перерахунку на абсолютно суху речовину (АСР).

Таблиия 2. Хімічний склад курячого посліду в перерахунку на абсолютно суху речовину

\begin{tabular}{|c|c|c|}
\hline № & Складова частина (компонент) & Вміст, \% \\
\hline 1 & Загальний азот & $24,3 \pm 0,03$ \\
\hline 2 & Ліпіди & $2,4 \pm 0,02$ \\
\hline 3 & Клітковина & $20,3 \pm 0,2$ \\
\hline 4 & Інші вуглеводи & $16,0 \pm 0,2$ \\
\hline 5 & $\mathrm{P}_{2} \mathrm{O}_{5}$ & $1,6 \pm 0,03$ \\
\hline 6 & $\mathrm{~K}_{2} \mathrm{O}$ & $2,6 \pm 0,2$ \\
\hline
\end{tabular}

Для визначення потенційної можливості ефективного використання даних забруднювачів навколишнього середовища як субстратів для отримання біобутанолу було проведено визначення хімічного складу стандартних субстратів, що використовуються в промисловості і для виділення мікроорганізмів продуцентів бутанолу. Наведені субстрати використовувались як контрольні, а саме: зернові культури - кукурудза, пшениця, жито, овес, та картопля. Дані про їх хімічний склад наведені в табл. 3.

Таблиия 3. Хімічний склад використаних натуральних середовищ, \%

\begin{tabular}{|c|c|c|c|c|c|}
\hline Показники & Кукурудза & Пшениця & Жито & Ячмінь & Овес \\
\hline Вода & 13,32 & 13,37 & 13,37 & 12,95 & 12,81 \\
\hline Азотисті речовини & 9,58 & 12,03 & 11,19 & 9,68 & 10,25 \\
\hline Клітковина & 2,65 & 2,31 & 2,16 & 4,40 & 9,97 \\
\hline Зола & 1,47 & 1,77 & 2,24 & 2,50 & 3,00 \\
\hline Жир & 5,09 & 1,85 & 1,68 & 1,96 & 5,27 \\
\hline Крохмаль & 55,00 & 55,00 & 52,00 & 48,00 & 40,00 \\
\hline
\end{tabular}

Отже, визначивши склад основних компонентів сироватки (табл.1) та курячого посліду (табл. 2) та порівнявши їх зі складом стандартних для 
проведення ацетоно-бутилового бродіння зернових середовищ (табл. 3), можна припустити, що наведені відходи промисловості (молочна сироватка, пташиний послід) можуть бути використані для отримання біобутанолу як основні, єдині або допоміжні компоненти субстрату для ацетоно-бутилового зброджування.

Дослідження динаміки зміни рН в процесі ацетоно-бутилового бродіння. Значення $\mathrm{pH}$ середовища дуже важливе для ацетоно-бутилового бродіння. Під час кислотоутворення швидке накопичення оцтової і масляної кислот викликає зменшення $\mathrm{pH}$. Утворення розчинників починається, коли $\mathrm{pH}$ досягає критичного значення $(4,5)$, після якого кислоти реасимілюються, і утворюється бутанол та ацетон. Тому низьке значення $\mathrm{pH}$ - передумова для виробництва розчинників [16]. Проте, якщо $\mathrm{pH}$ падає нижче 4,5 до того, як синтезується достатня кількість кислот, утворення розчинників буде коротким і непродуктивним.

Було перевірено п'ять штамів мікроорганізмів роду Clostridium для визначення найактивніших продуцентів бутанолу та відмічена їх загальна тенденція до зміни рН при зброджуванні. Дослідження проводили на 6\% житньому заторі. 3 проведених досліджень видно (рис. 1), що початкове значення $\mathrm{pH}$ близьке до нейтрального. Це свідчить, що середовище придатне для розмноження ацетоно-бутилових бактерій (при рН нижче 4,0-4,1 та вище 7,0-7,1 розвиток бактерій повністю припиняється) та утворення ними максимальної кількості розчинників.

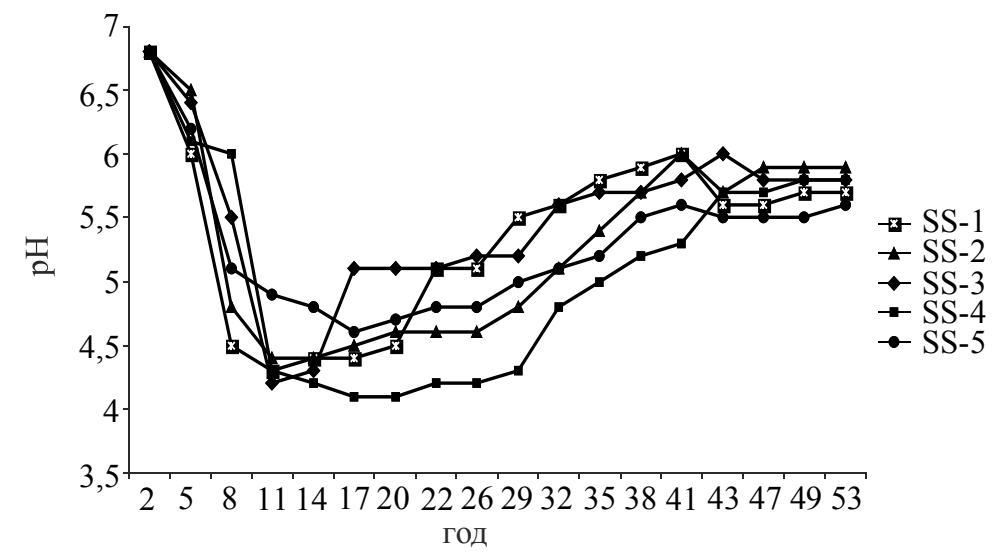

Рис. 1. Динаміка зміни рН середовища при культивуванні ацетоно-бутилових бактерій

Упродовж 12-14 год бродіння спостерігається швидке зниження $\mathrm{pH}$. Це пов'язане 3 тим, що на першій фазі бродіння утворюються більш окислені продукти - кислоти. На наступних 24-25 год росту $\mathrm{pH}$ середовища різко підвищується. Це пов'язано з тим, що бродіння вступає в другу фазу, яка характеризується утворенням нейтральних продуктів - розчинників. У другій фазі швидкість бродіння є найвищою на 28 годині при $\mathrm{pH} 4,4-5,2$.

Після закінчення бродіння спостерігається різке підвищення значення $\mathrm{pH}$, яке можна пояснити утворенням значної кількості нейтральних продуктів розчинників (ацетон, бутанол, етанол). 
Проаналізувавши отримані дані, можна зробити висновок, що штами SS-2, SS-3, SS-4 дали позитивний результат. Значення $\mathrm{pH}$ відповідало межам коливання, зазначеним вище. Штами SS-1 та SS-5 не повністю відповідали зазначеним вимогам зміни $\mathrm{pH}$ : зокрема, у SS-5 упродовж 12-14 год не спостерігалось різкого зниження значення $\mathrm{pH}$, а у штаму SS-1 на 28 годині бродіння значення $\mathrm{pH}$ зростало повільно. Варто зазначити, що найменшу кількість розчинників утворювали саме штами SS-1 та SS-5. Очевидно це пов'язано із відхиленнями значень рН при бродінні.

Слід зазначити, що біохімічні шляхи метаболізму мікроорганізмів під впливом $\mathrm{pH}$ середовища можуть різко змінюватися. Замість нормальних продуктів, які утворюють мікроорганізми при оптимальному значенні $\mathrm{pH}$ середовища, можуть утворюватися зовсім інші хімічні речовини, якщо ця реакція зміниться, або буде утворюватися менша кількість продукту (як у нашому випадку).

Дослідження синтезу бутанолу залежно від складу натурального поживного середовища. Для дослідження інтенсивності синтезу бутанолу виділеними раніше АББ використовували 6\% ячмінний, житній, кукурудзяний, пшеничний і вівсяний затори, а також середовище Рушмана (рис. 2). Найбільша кількість бутанолу синтезувалась на житньому середовищі, максимальна його кількість була утворена штамом SS-2, і становила 11,2 г/л, зразки SS-3 та SS-4 синтезували меншу кількість бутанолу - 10,9 г/л та 10,66 г/л відповідно. Ізоляти SS-1 та SS-5 при культивуванні на житньому середовищі продукували на $12 \%$ менше бутанолу порівняно з іншими зразками.

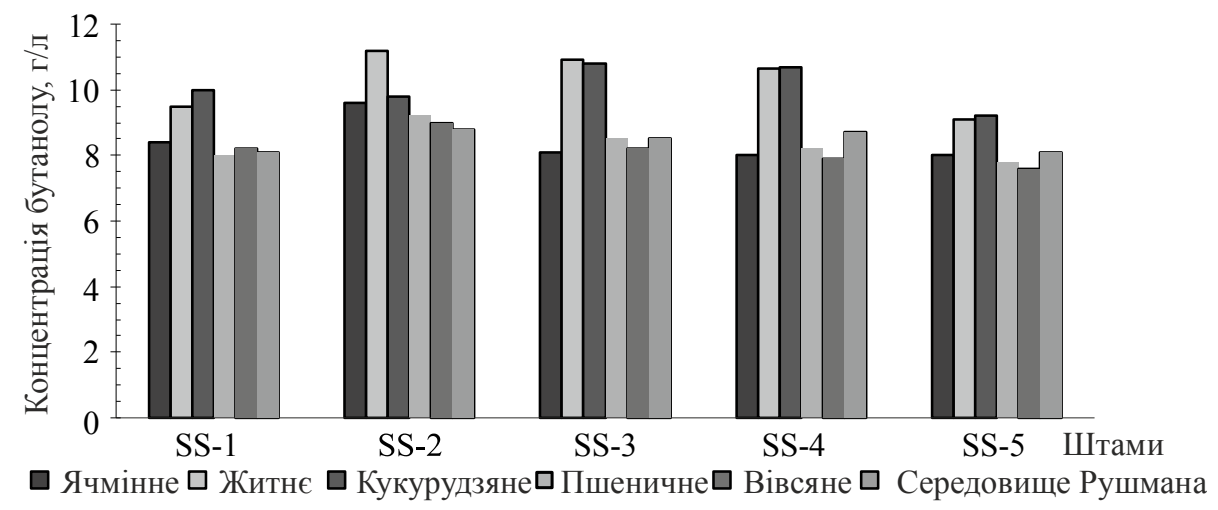

Рис. 2. Концентрація бутанолу за культивування бактерій роду Clostridium на природних поживних середовищах

Щодо синтезу бутанолу на кукурудзяному середовищі, то максимальна його кількість була утворена зразками SS-3 та SS-4 і становила, відповідно, 10,8 г/л та 10,7 г/л. Інші ізоляти на кукурудзяному середовищі синтезували на $10 \%$ меншу кількість бутанолу. Найменша кількість бутанолу на кукурудзяному середовищі була утворена зразком щтамуSS-5 і становила 9,2 г/л.

Вирощування на ячмінному заторі характеризувалось на $16,2 \%$, а на середовищі Рушмана на 14,25\% нижчими показниками синтезу бутанолу порівняно з кукурудзяним і житнім середовищами. 
Підсумовуючи отримані результати, можна зробити висновок, що найоптимальнішими для синтезу розчинників виявились житнє та кукурудзяне середовища. На ячмінному середовищі синтез розчинників спостерігався на $16,5 \%$, а на середовищі Рушмана на 20,9\% менше порівняно із житнім середовищем. Очевидно це можна пояснити хімічним складом кукурудзяного та житнього середовищ (табл. 3), а саме: вмістом крохмалю (55\%, 52\%). При аналізі досліджуваних зразків виявили, що найбільш активним по синтезу розчинників був ізолят ацетоно-бутилових бактерій SS-2, проте зразки SS-3 та SS-4 показали менші результати лише на 3,3\%, а досліджувані ацетоно-бутилові бактерії SS-1 та SS-5 показали менші результати на 10,3\% та 11,9\%, відповідно, порівняно з ізолятом SS-2.

Дослідження синтезу біобутанолу на курячому посліді та молочній сироватиі. Для дослідження інтенсивності синтезу бутанолу на курячому посліді та молочній сироватці використовували 6\% (по АСР) розчини вказаних субстратів та їхню суміш (курячий послід/сироватка - 30/70\% відповідно). Дані щодо синтезу бутанолу досліджуваними зразками АББ наведені на рис. 3.

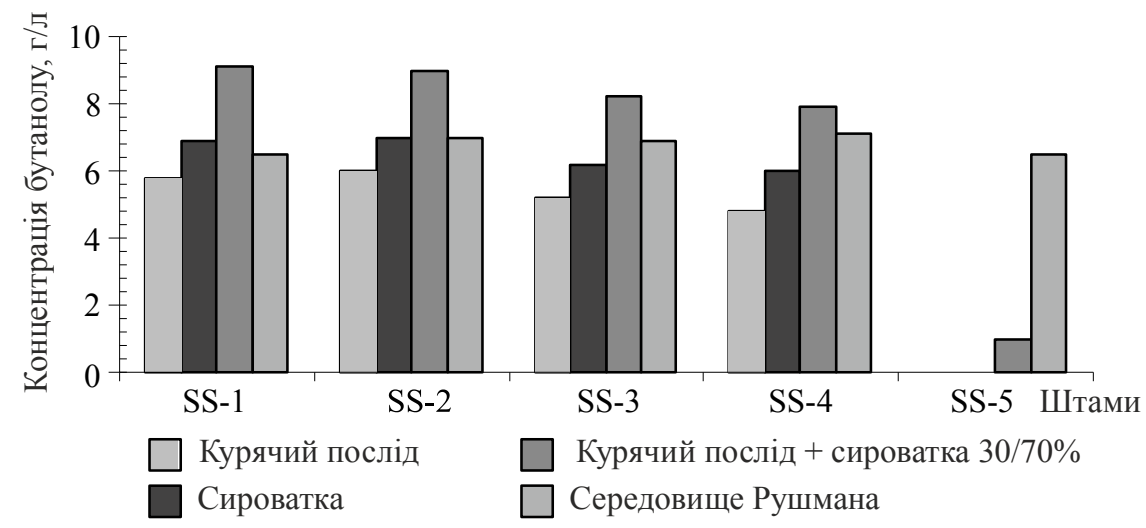

Рис. 3. Дослідження синтезу бутанолу на курячому посліді та молочній сироватці

Найбільша кількість бутанолу синтезувалась на суміші сироватки 3 курячим послідом, максимальна його кількість була утворена штамом SS-2 і становила 9,2 г/л, штами SS-3 та SS-4 синтезували меншу кількість бутанолу 8,4 г/л та 8,2 г/л відповідно. Ізоляти SS-1 та SS-4 при культивуванні на середовищі з курячим послідом характеризувались на $12 \%$ меншими показниками синтезу бутанолу порівняно з іншими зразками.

Щодо синтезу бутанолу на середовищі з молочною сироваткою, то максимальна його кількість була утворена щтамами SS-1 та SS-2 і становила 6,9 г/л та 7,0 г/л відповідно. Інші ізоляти на середовищі з молочною сироваткою синтезували на $10 \%$ меншу кількість бутанолу. Найменша кількість бутанолу була синтезована на середовищі з курячим послідом штамом SS-4 і становила 4,8 г/л. Штам SS-5 майже не мав здатності до зброджування даних субстратів.

Інтенсивність продукування органічних розчинників штамами SS-1 та SS-4 корелювала 3 показниками, які були відмічені при бродінні даних штамів на стандартних зернових середовищах. 


\section{Висновки}

Дослідження проводились як початковий первинний відбір активних штамів роду Clostridium, здатних до ацетоно-бутилового зброджування нестандартних субстратів, так і самих субстратів, що створюють значні екологічні проблеми та потребують ефективної утилізації. Отримані результати інтенсивності бродіння як на стандартних, так і на альтернативних субстратах $€$ досить обнадійливими щодо перспективи використання штамів для відпрацювання ефективних технологій отримання органічних розчинників, зокрема бутанолу.

\section{Лiтература}

1. Свириденко Ю.Я. Эффективный подход к переработке молочной сыворотки / Ю.Я Свириденко, Т.А. Волкова // Молочная промышленность. — 2012. — № 7. - С. $44-45$.

2. Волкова T.A. Перспективные направления переработки молочной сыворотки / Т.А. Волкова // Переработка молока. - 2014. - № 5. - С. 6 -9.

3. Максимюк Н.Н. Биотехнологические аспекты переработки белковых отходов животного происхождения / Н.Н. Максимюк, А.Н. Денисенко, Д.С. Мисак // Фундаментальные исследования. - 2006. - № 9. - С. $44-45$.

4. Сироватка молочна - біологічно цінний продукт / О.А. Чернюшок, О.В. Кочубей-Литвиненко, В.П. Василів та ін. // Харчова наука і технологія. — 2011. — № 1(14). — С. $40-42$.

5. Analysis of the mechanism and regulation of lactose transport and metabolism in Clostridium acetobutylicum ATCC 824 / Y.Yu, M. Tangney, H.C. Aass, W.J. Mitchell // Appl. Environ. Microbiol. — 2007. — Vol. 73, № 6. — P. 1842-1850.

6. Екологічна оцінка стану довкілля в зонах виробництва продукції птахівництва / В.П. Бородай, О.В. Тертична, М.П. Кейван та ін. // Екологія. — 2014. — № 4(137). — С. 22-25.

7. Мельник B.O. Пташиний послід: вихід, хімічний склад та основні способи переробки. — 19.09.2015 [Електронний ресурс]. — Режим доступу : http://avianua.com/ua/index.php/statty-po-pticevodstvu/tekhnolohiia-ptakhivnytstva/40-ptashinij-poslid-himichnyj-sklad.

8. Пискаева А.И. Анализ способов переработки сельскохозяйственных органических отходов на примере куриного помета / А.И. Пискаева // Аэкономика: экономика и сельское хозяйство. 2016. — № 4(12) [Електронний ресурс]. — Режим доступу : http://aeconomy.ru/science/agro/analizsposobov-pererabotki-selskokh/.

9. Gerber P. Poultry production and the environment - a review / P. Gerber, C. Opio, H. Steinfeld // Proceedings of the International Conference Poultry in the Twenty-First Century: Avian Influenza and Beyond. - 2008. - P. 379-405.

10. Лысенко В.П. Биопрепараты для компостирования птичьего помета / В.П. Лысенко, Г.Е. Мерзлая, Р.А. Афанасьев // Птицеводство. - 2014. - № 3. - С 39-44.

11. Ястремська Л.С. Поживні середовища на основі відходів птахо-фабрик для вирощування мікроорганізмів різних таксономічних груп / Л.С. Ястремська, Т.П. Крищтаб // Сільськогосподарська мікробіологія. - 2010. - Вип. 12. - С.114-123.

12. Скроцька O.I. Виділення ацетоно-бутилових бактерій з різних природних джерел / О.І. Скроцька, Ю.М. Пенчук, С.О. Скроцький, М.М. Гавриленко // Харчова промисловість. - 2010. - № 9. - С. 49-52.

13. Логоткин И.С. Технология ацетоно-бутилового производства / И.С. Логоткин Москва : Пищепромиздат, 1958. - 267 с.

14. Лакин Г.Ф. Биометрия / Г.Ф. Лакин. - Москва : Высшая школа, 1980. - 293 с.

15. Лапач С.Н. Статистические методы в медико-биологических исследованиях с применением «Excel» / С.Н. Лапач, А.В. Чубенко, П.Н. Бабич. — Киев : Морион, 2000. - 320 с.

16. Control of carbon and electron flow in C. acetobutylicum fermentations: utilization of carbon monoxide to inhibit hydrogen production and to enhance butanol yields / B.H. Kim, P. Bellows, R. Datta, J.G. Zeikus // Appl. Environ. Microbiol. — 1984. — Vol. 48. — P. 764 -770. 